\title{
Effect of 32/67 kDa laminin-binding protein antibody on mouse embryo implantation
}

\author{
C. Zhang ${ }^{1,2}$, E. Duan ${ }^{1 *}$, Y. Cao ${ }^{1}$, G. Jiang and G. Zeng ${ }^{1}$ \\ ${ }^{1}$ State Key Laboratory of Reproductive Biology, Institute of Zoology, Chinese Academy of Sciences, Beijing 100080, PR China; and \\ ${ }^{2}$ Molecular Oncology and Development Program, 331 Boyer Center for Molecular Medicine, Yale Medical School, \\ New Haven, CT 06510, USA
}

\begin{abstract}
Mouse embryo implantation depends on the complex interaction between the embryo trophoblast cells and the uterine environment, which deposits an extracellular matrix with abundant amounts of laminin. Intrauterine injection and blastocyst or ectoplacental cone culture models were used to study the effect of $32 / 67 \mathrm{kDa}$ lamininbinding protein antibody on mouse embryo implantation in vivo and in vitro. Intrauterine injection of $32 / 67 \mathrm{kDa}$ laminin-binding protein antibody $(0.4 \mathrm{mg}$ in $1 \mathrm{ml}$ Ham's F-10 medium, $5 \mu$ l per mouse) into the left uterine horns of mice $(n=22)$ on day 3 of pregnancy inhibited embryo implantation significantly $(P<0.001)$ compared with the contralateral horns that had been injected with normal rabbit IgG. A continuous section study on day 5 after injection showed that the embryos in the control uteri implanted normally and developed healthily, but there were no embryos or the remaining embryos had disintegrated in the uteri injected with 32/67 kDa lamininbinding protein antibody. Blastocysts or ectoplacental cones were cultured in media containing $32 / 67 \mathrm{kDa}$ laminin-binding protein antibody $\left(0.2 \mathrm{mg} \mathrm{ml}^{-1}\right)$ on laminincoated dishes with normal rabbit IgG at the same concentration as in the controls. The $32 / 67 \mathrm{kDa}$ laminin-binding protein had no effect on blastocyst or ectoplacental cone attachment, but prohibited the blastocyst or ectoplacental cone outgrowth and primary or secondary trophoblast giant cell migration. These results indicate that $32 / 67 \mathrm{kDa}$ laminin-binding protein antibody blocked mouse embryo implantation by preventing embryo trophoblast cell invasion and migration through the uterine decidual basement membrane-like extracellular matrix which has a high laminin content.
\end{abstract}

\section{Introduction}

Mouse embryo implantation depends on the interactions between the trophoblast cells and the surrounding uterine environment. During normal development, the initial invasion by primary trophoblast stimulates the differentiation of the uterine stromal fibroblasts to decidua. The stromal cells increase in size and deposit a pericellular basement membrane-like matrix consisting of laminin, fibronectin, and collagen type IV (Wewer et al., 1986). The secondary trophoblast, derived from the ectoplacental cone (EPC), invades the decidua and forms contacts with the maternal blood supply that lead to the establishment of a haemochorial placenta (Schlafke and Enders, 1975; Romagnano and Babiarz, 1993).

Conversion of the epithelial trophectoderm to invasive trophoblast begins at the late blastocyst stage, and comprises a change in adhesive behaviour and the onset of motility. The first signs of embryo outgrowth are detected about $10-15 \mathrm{~h}$

${ }^{*}$ Correspondence.

Received 7 July 1999. after the embryo hatches from the zona pellucida, when the previously quiescent trophectoderm cells exhibit an abrupt onset of protrusive activity followed by attachment and spreading on the substratum (Sutherland et al., 1993).

Attachment and outgrowth of both primary (Armant et al., 1986) and secondary (Romagnano and Babiarz, 1990) trophoblast cells are supported by laminin in vitro. Laminin is a multidomain glycoprotein containing active sites that promote the adhesion and migration of many cell types, including metastatic cells (Beck et al., 1990). YIGSR (Tyr-IleGly-Ser-Asp) located on the $B_{1}$ chain (Graf et al., 1987), IKVAV (Ile-Lys-Val-Ala-Val) on the long arm (Tashiro et al., 1989) and RGD (Arg-Gly-Asp) on the short arm (Grant et al., 1989) of the A chain are the main functional peptide sequences of laminin. The YIGSR peptide sequence is recognized by a $67 \mathrm{kDa}$ laminin-binding protein (LBP) (Graf et al., 1987), while IKVAV is recognized by laminin-binding proteins of 32, 45, 67 and $80 \mathrm{kDa}$ (Clement et al., 1990), and there is an immunological relationship among these proteins. The cDNA clone of the $67 \mathrm{kDa}$ laminin-binding protein predicts a $32 \mathrm{kDa}$ protein (Wewer et al., 1986 and Yow et al., 1988), and antiserum to the $32 \mathrm{kDa}$ protein recognizes the 32 , 
45 and $67 \mathrm{kDa}$ laminin-binding proteins (Mercurio and Shaw, 1988; Thompson et al., 1989). The RGD sequence is recognized by the integrin family of receptors, such as $\alpha_{1} \beta_{1}$ and $\alpha_{\mathrm{v}} \beta_{3}$, and the developmental regulation of integrin expression appears to have functional significance for trophoblast invasion of the laminin-rich uterine stroma (Sutherland et al., 1993). The $32 / 67 \mathrm{kDa}$ LBPs are laminin non-integrin receptors and express on trophoblast cell surfaces (Romagnano and Babiarz, 1993). The present study investigated the effect of $32 / 67 \mathrm{kDa}$ LBP antibody on mouse embryo implantation using an in vivo and in vitro implantation model. This antibody was rabbit serum made from a 17-amino-acid peptide from the $\mathrm{N}$-terminus (residues 25-41) of the mouse $67 \mathrm{kDa}$ LBP cDNA clone encoding a $32 \mathrm{kDa}$ protein (Clement et al., 1990), which forms a $67 \mathrm{kDa}$ mature protein by dimerization (Landoski et al., 1995).

\section{Materials and Methods}

\section{Materials}

Mouse laminin from Englebreth-Holm-Swarm (EHS) tumour basement membrane was obtained from Sigma Chemical Co. (St. Louis, MO). Ham's F-10 nutrient mixture and fetal calf serum (FCS) were purchased from Gibco BRL (Grand Island, NY). Rabbit anti-32/67 kDa IgG was a gift from H. Kleinman (National Institute of Dental Research, $\mathrm{NIH}$, Bethesda, MD).

\section{Animals}

Young adult female mice (25-30 g) of the Kunming white strain were obtained from the Feed Lot of the Zoo, Institute of Zoology, Chinese Academy of Sciences (Beijing) and maintained at $22-25^{\circ} \mathrm{C}$ on a $14 \mathrm{~h}$ light: $10 \mathrm{~h}$ dark cycle. Female mice were mated naturally with 12 -week-old males of the same strain (one female:one male in a cage overnight) for the intraluminal injection of antibody experiment. Other females were superovulated by injecting i.p. 7.5 iu eCG (Institute of Changchun Biological product, Department of Health, China), and then, approximately $48 \mathrm{~h}$ after eCG injection, these females were injected i.p. with 7.5 iu hCG (Institute of Zoology, Chinese Academy of Sciences, China) and then impregnated in a similar way. Mating was evidenced by the appearance of a vaginal plug the next morning. The day of the appearance of a vaginal plug was designated as day 1 of pregnancy and from this time, animals were caged separately.

\section{Intrauterine injection}

Naturally ovulated animals were prepared as described by Zhu et al. (1995) on day 3 of pregnancy. In the experimental group of 22 mice, the left uteri were injected with $5 \mu \mathrm{l} 32 / 67 \mathrm{kDa}$ LBP IgG $\left(0.4 \mathrm{mg} \mathrm{ml}^{-1}\right.$ in Ham's F-10 medium) by syringe via the uterine horns, where the oviduct connects with uterus. All the right uteri were injected with
$5 \mu \mathrm{l}$ normal rabbit IgG at the same concentration in Ham's F10 medium as in the control group. The animals appeared healthy throughout the experiment and were killed by $\mathrm{CO}_{2}$ inhalation on day 5 after injection, and the numbers of implanted embryos were counted under a dissecting microscope.

\section{Morphological analysis}

Embryo implantation in the uteri of rabbits injected with normal rabbit IgG was compared with that in uteri treated with $32 / 67 \mathrm{kDa}$ LBP IgG. On day 5 after intrauterine injection, the right and left uteri were removed and fixed in $10 \%(\mathrm{v} / \mathrm{v})$ formalin in PBS for haematoxylin and eosin staining.

\section{Blastocyst collection and culture}

Blastocysts were flushed from the uteri on day 4 of pregnancy with uterus flush medium (UFM: serum-free Ham's F-10 supplemented with $1.6 \mathrm{mg} \mathrm{NaHCO} \mathrm{ml}^{-1}, 0.3 \mathrm{mg}$ L-glutamine $\mathrm{ml}^{-1}, 0.24 \mathrm{mg}$ calcium lactate $\mathrm{ml}^{-1}$ and $400 \mathrm{U}$ Gentamycini sulfatis $\mathrm{ml}^{-1}$; Gibco BRL, Grand Island, NY). After three washes with UFM, these blastocysts were transferred to microdrops $(50 \mu \mathrm{l})$ under mineral oil on $35 \mathrm{~mm}$ tissue culture dishes (Falcon 1008; Becton-Dickinson, Lincoln Park, NJ). The blastocysts were cultured in a $5 \% \mathrm{CO}_{2}$ humidified air incubator at $37^{\circ} \mathrm{C}$ with blastocyst hatching medium (UFM supplemented with $4 \mathrm{mg} \mathrm{BSA} \mathrm{ml}^{-1}$ and $3.67 \times 10^{-6} \mathrm{~mol}$ oestradiol $\mathrm{l}^{-1}$; Sigma, St Louis, MO) for $24 \mathrm{~h}$ (Zeng and Cao, 1996). The blastocysts hatched from the zona pellucida were collected and transferred randomly to blastocyst culture medium (UFM supplemented with $1 \%$ heat-inactivated FCS) containing 32/67 kDa LBP IgG (0.2 mg $\mathrm{ml}^{-1}$ ) or normal rabbit IgG at the same concentration and cultured for $48 \mathrm{~h}$. The culture dishes were pre-coated at room temperature for $3 \mathrm{~h}$ under a clean air hood with $5 \mu \mathrm{l}$ laminin $\left(1 \mathrm{mg} \mathrm{ml}^{-1}\right)$.

\section{Isolation and culture of ectoplacental cone}

Female mice were killed on day 8 of pregnancy and uteri were removed to Hank's balanced salt solutions (HBSS) for dissection. Decidual capsules were removed from the uterus and split open with fine forceps. The embryo and attached trophoblast were separated from the surrounding decidua. EPCs were dissected at the junction with the extraembryonic ectoderm by fine needles and moved to culture dishes using pipettes. Any maternal blood surrounding the EPC was removed by washing six times with HBSS. EPCs were cultured in Ham's F-10 medium containing 4\% heatinactivated FCS, which was optimal for EPC growth (Zhang et al., 1995), with $32 / 67 \mathrm{kDa} \operatorname{LBP} \operatorname{IgG}\left(0.2 \mathrm{mg} \mathrm{ml}^{-1}\right)$ or normal rabbit IgG at the same concentration for $48 \mathrm{~h}$. The 24-well dishes were pre-coated at room temperature for $3 \mathrm{~h}$ in the air clean bench with $10 \mu \mathrm{l}$ laminin $\left(1 \mathrm{mg} \mathrm{ml}^{-1}\right)$. 


\section{Data collection and statistical analysis}

Implanted embryos were identified by the presence of a decidual capsule. Blastocyst or EPC attachment and outgrowth percentages were recorded under an Olympus inverted phase-contrast microscope at $48 \mathrm{~h}$. The migrating distance of primary (PTGC) or secondary trophoblast giant cells (STGC) from the inner cell mass (ICM) or EPC rudiment was measured by eyepiece grid. The quantitative data are given as means \pm SEM and were analysed by Student's $t$ test for paired comparisons (in vivo results) or ANOVA with Scheffé's test (in vitro results). Differences were considered significant at $P<0.05$.

\section{Results}

Effect of 32/67 kDa laminin-binding protein IgG intrauterine injection on mouse embryo implantation

The animals appeared healthy throughout the experiment and were killed on day 5 after the intrauterine injection. In 22 naturally ovulated mice, the mean number of implanted embryos for each uterus injected with $32 / 67 \mathrm{kDa}$ LBP IgG was $2.17 \pm 1.04(n=48)$, compared with $6.19 \pm 1.22(n=136)$ in each contralateral uterus injected with normal rabbit IgG. This difference was significant $(P<0.001)$, indicating that administration of $32 / 67 \mathrm{kDa}$ LBP IgG blocked mouse embryo implantation.

\section{Morphological analysis of intrauterine-injected uteri}

During normal mouse embryo implantation, the embryo attached to and invaded the uterine epithelium on day 5 of pregnancy (Fig.1a,b). The serial sections on the day 5 after intrauterine injection (day 8 of pregnancy) showed that embryos in control uteri implanted normally and developed healthily (Fig. 1c). However, there were no embryos or the remaining embryos were abnormal and had disintegrated in the $32 / 67 \mathrm{kDa}$ LBP IgG injected uteri (Fig. 1d). The remaining embryos were usually localized at the bottom of the uterus, away from the uterine horn where the antibody was injected.
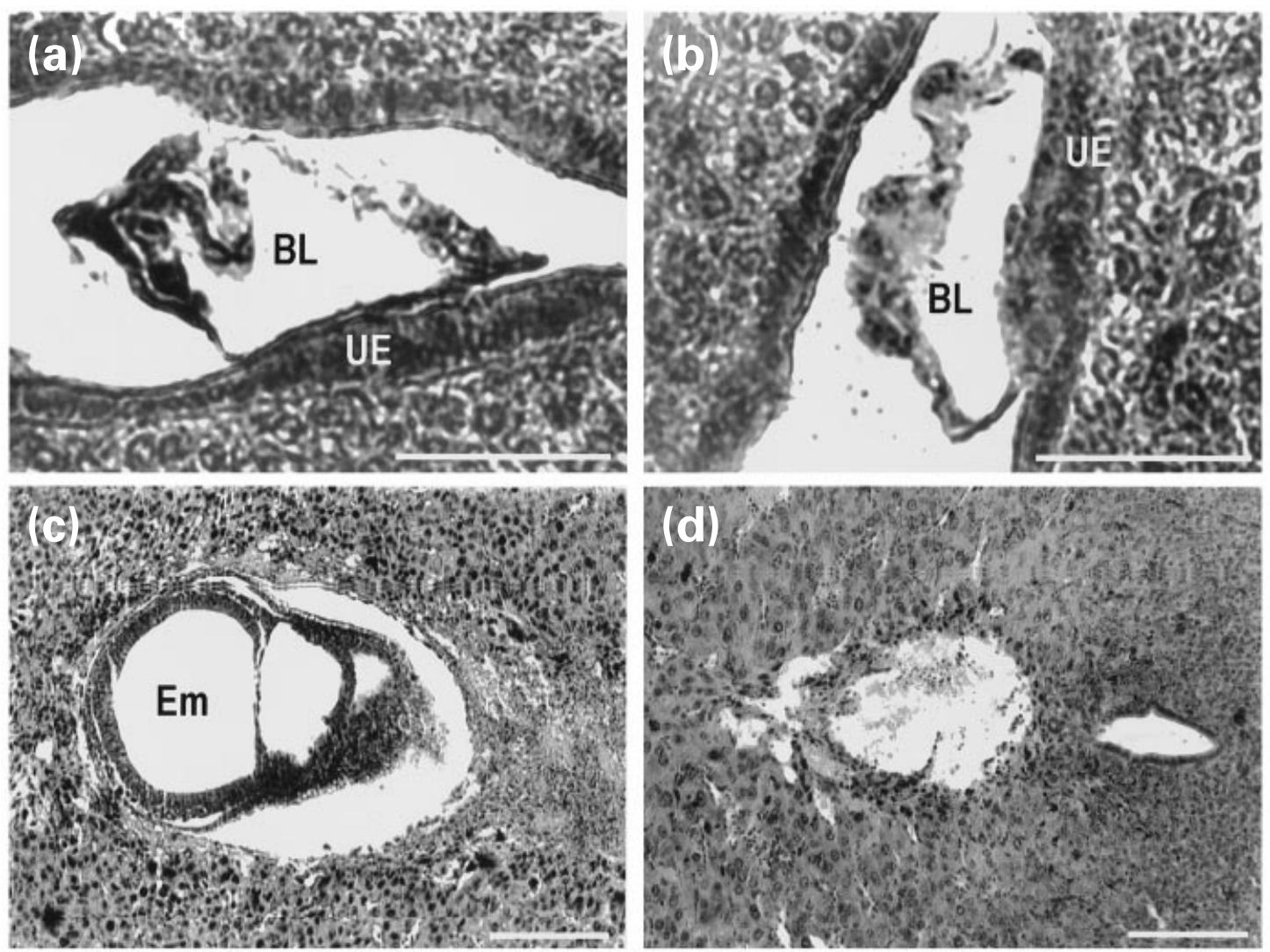

Fig. 1. Morphology of mouse embryo implantation (paraffin wax sections stained with haematoxylin and eosin). Uteri injected with normal rabbit IgG (a-c) compared with uteri injected with $32 / 67 \mathrm{kDa}$ laminin-binding protein IgG-treated uteri (d). (a,b) The process of mouse embryo attachment and invasion to the uterine epithelium on day 5 of pregnancy. (c,d) Implantation site sections of the identical mouse right and left uteri on day 5 after intrauterine injection. The embryo in (c) implanted successfully and developed normally, while the remaining embryo in the 32/67 kDa LBP antibody-injected uterus (d) degenerated and disintegrated. BL, blastocyst; Em, embryo; UE, uterine epithelium. Scale bars represent $40 \mu \mathrm{m}$. 


\section{Blastocyst and ectoplacental cone culture assays}

The hatched blastocysts were cultured on laminin (Fig. 2a). Laminin promoted blastocyst outgrowth, which consisted of a monolayer of spreading trophoblast cells with the ICM remaining on top in the medium containing normal rabbit IgG (Figs $2 \mathrm{~b}$ and 3 ). Blastocyst outgrowth and PTGC migration were inhibited in the medium containing 32/67 kDa LBP IgG (Figs 2c and 3). Laminin promoted EPC outgrowth, which consisted of a monolayer of migrating STGC with the EPC remaining on top in the medium containing normal rabbit IgG (Fig. 2d). EPC outgrowth or STGC migration from the EPC rudiment was inhibited in the medium containing 32/67 kDa LBP IgG (Figs 2e and 3). However, the presence of $32 / 67 \mathrm{kDa}$ LBP IgG did not affect blastocyst or EPC attachment, although it did inhibit EPC attachment slightly (Fig. 3).

\section{Discussion}

Cell-matrix interactions are likely to be particularly important for trophoblast differentiation and invasion during implantation. Laminin is a major component of the decidualized uterine stroma which the trophoblast invades, and this matrix protein may influence trophoblast migration since its expression is upregulated at the time of implantation (Burrows et al., 1996).

Laminin has multiple cell-binding sites, such as the RGD of the A chain short arm, the YIGSR of the $B_{1}$ chain and the SIKVAV of the A chain long arm, which are recognized by various cell surface receptors. For example, RGD is recognized by members of the integrin superfamily (Sutherland et al., 1993). YIGSR or SIKVAV may be potential laminin-binding sites for the $67 \mathrm{kDa}$ laminin-binding protein (Romagnano and Babiarz, 1993).

A $67 \mathrm{kDa}$ protein has been identified as a laminin receptor in tumour and muscle cells, and Wewer et al. (1986) reported a partial cDNA encoding the human $67 \mathrm{kDa}$ protein. Several groups (for example, Yow et al., 1988) have isolated human and mouse full-length cDNA, the deduced amino acids sequences of which match the cDNA clone described by Wewer et al. (1986). However, these full-length cDNA clones code a 32 but not a $67 \mathrm{kDa}$ protein. The $32 \mathrm{kDa}$ protein has been identified as a cell-surface, laminin-binding protein in various cells, and antibodies to a bacterial fusion protein from a full-length clone for the $32 \mathrm{kDa}$ protein recognize the 32,45 and $67 \mathrm{kDa}$ proteins. These proteins may be encoded by distinct genes while sharing a common epitope (Clement et al. 1990).
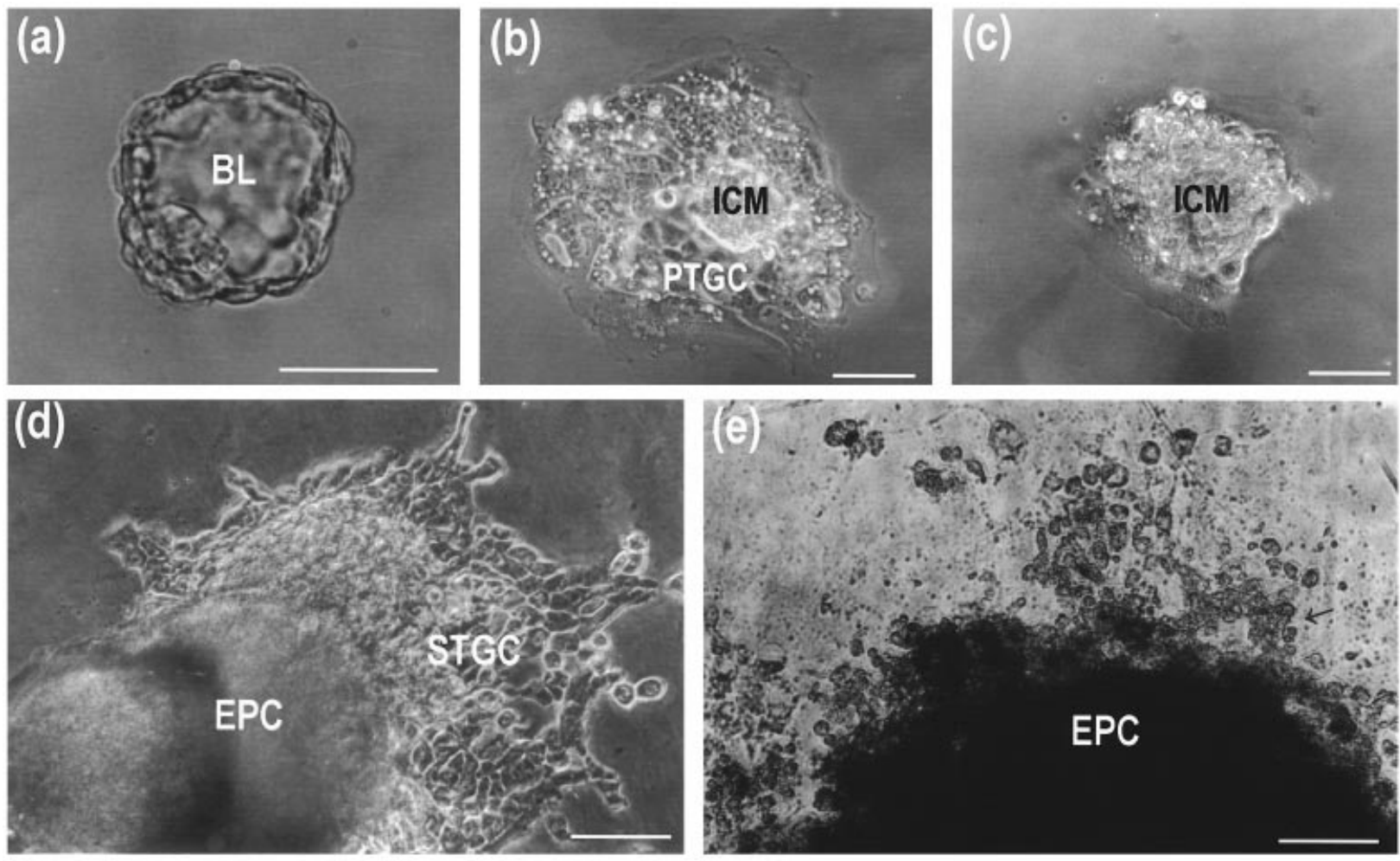

Fig. 2. Mouse blastocyst or ectoplacental cone (EPC) culture on laminin. (a) Hatched blastocyst. (b) Blastocyst outgrowth and migration of primary trophoblast giant cells (PTGCs) in medium containing normal rabbit $\operatorname{IgG}\left(0.2 \mathrm{mg} \mathrm{ml}^{-1}\right)$. (c) Inhibition of blastocyst outgrowth and PTGC migration in the presence of $32 / 67 \mathrm{kDa}$ laminin-binding protein (LBP) $\operatorname{IgG}\left(0.2 \mathrm{mg} \mathrm{ml}^{-1}\right)$. (d) EPC outgrowth and migration of secondary trophoblast giant cells (STGCs) in medium containing normal rabbit $\operatorname{IgG}\left(0.2 \mathrm{mg} \mathrm{ml}^{-1}\right)$. (e) Inhibition of EPC outgrowth and STGC migration in the presence of $32 / 67 \mathrm{kDa}$ LBP IgG $\left(0.2 \mathrm{mg} \mathrm{ml}^{-1}\right)$. BL, blastocyst; ICM, inner cell mass. Scale bars represent $50 \mu \mathrm{m}$. 


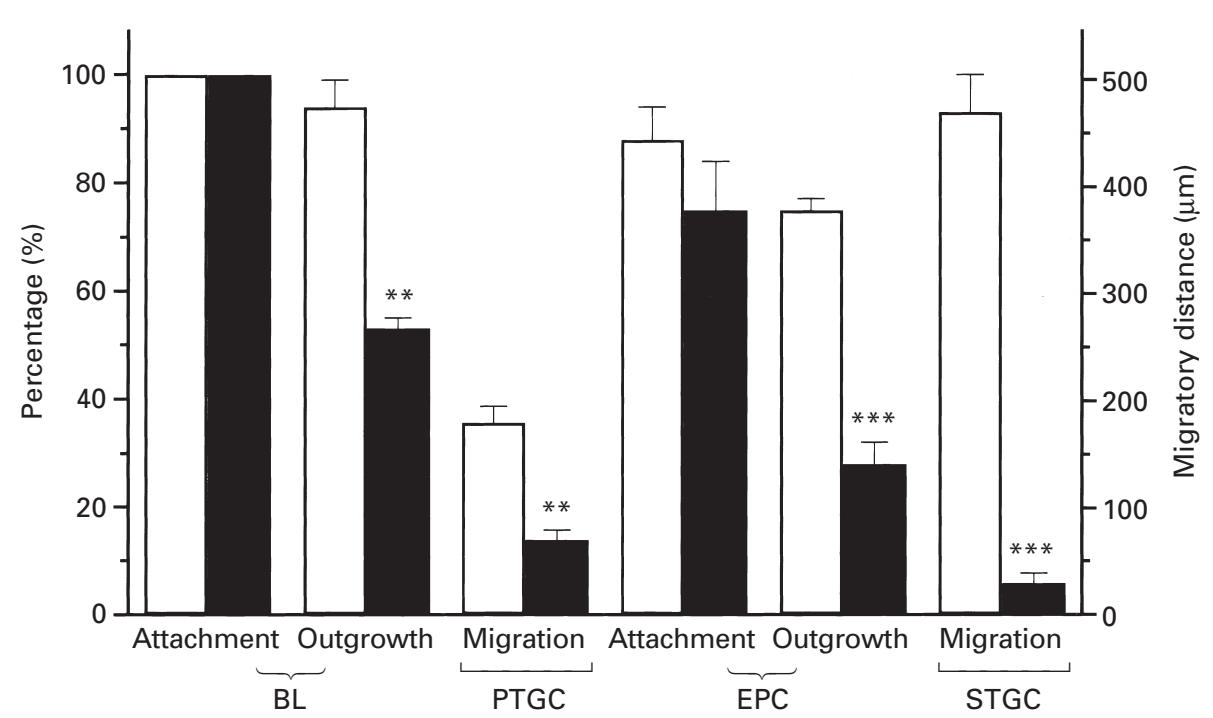

Fig. 3. Effect of $32 / 67 \mathrm{kDa}$ laminin-binding protein (LBP) $\operatorname{IgG}$ to mouse blastocyst or ectoplacental cone (EPC) attachment, outgrowth and migration of primary (PTGCs) or secondary trophoblast giant cells (STGCs) on laminin. 32/67 kDa LBP IgG did not affect blastocyst (BL) or EPC attachment, and inhibited blastocyst and EPC outgrowth and PTGC or STGC migration. $\square$, Normal rabbit $\operatorname{IgG}\left(0.2 \mathrm{mg} \mathrm{l}^{-1}\right)$; $\mathbf{\square}, 32 / 67 \mathrm{kDa} \operatorname{LBP} \operatorname{IgG}\left(0.2 \mathrm{mg} \mathrm{l}^{-1}\right)$. There were at least 25 blastocysts or EPCs in each group and the experiment was repeated three times. Asterisks represent signficant differences: ${ }^{* *} P<0.01 ;{ }^{* * *} P<0.001$.

The $32 / 67 \mathrm{kDa}$ LBP IgG was made with a peptide of 17 amino acids from the $\mathrm{NH}_{2}$ end of the $67 \mathrm{kDa}$ laminin-binding protein, the cDNA of which encodes a $32 \mathrm{kDa}$ protein. This antibody recognizes several laminin-binding proteins, including the 32 and $45 \mathrm{kDa}$ proteins (Clement et al., 1990). Several crossreacting proteins were found on mouse trophoblast (33, 41, 45, 62 and $76 \mathrm{kDa}$ ) (Romagnano and Babiarz, 1993). The antiserum also identifies IKVAV binding proteins isolated by affinity chromatography (Clement et al., 1990). Further details of the structure or binding specificities of these molecules remain controversial (Mecham, 1991).

A role for these proteins in trophoblast-laminin interaction is demonstrated by the inhibition of blastocyst or EPC outgrowth and PTGC or STGC migration in the presence of the antibody. The binding of $32 / 67 \mathrm{kDa}$ LBP IgG may not affect the ability of trophoblast to bind to laminin initially, but subsequent blastocyst or EPC outgrowth and PTGC or STGC migration may be inhibited by a decrease in protein mobility owing to antibody cross-linking of the laminin-binding proteins. The 32/67 kDa LBP IgG did not affect blastocyst or EPC attachment, which is consistent with the finding that the putative peptide substrate cyclic YIGSR had no effect on blastocyst attachment (Y. Cao, C. Zhang, E. Duan, G. Jiang and G. Zeng, unpublished), but inconsistent with an earlier EPC attachment experiment, in which cyclic YIGSR prevented EPC attachment on laminin in a dose-dependent manner (Zhang et al., 1996). Moreover, the attachment on laminin was also inhibited by incubating EPC with another putative peptide, IKVAV (Romagnano and Babiarz, 1993). The LBPs on secondary trophoblast from EPC may interact with different, uncharacterized active sites on laminin. The epitope of the $32 / 67 \mathrm{kDa}$ LBP antibody remains to be identified in order to resolve this puzzle.

The present study showed that $32 / 67 \mathrm{kDa}$ LBP IgG had no effect on blastocyst or EPC attachment, but prevented blastocyst or EPC outgrowth and primary or secondary trophoblast cell migration on laminin in vitro, and blocked embryo implantation in vivo. The results indicated that this antibody blocks implantation by preventing embryo trophoblastic cell invasion and migration through the uterine decidual basement membrane-like extracellular matrix, which is rich in laminin. Monkeys showed fetal loss after immunization with YIGSR (Chambers et al., 1995), which is a further demonstration that the interaction between LBPs and laminin is important for reproductive processes. A cell-laminin interaction via a $67 \mathrm{kDa}$ LBP has been shown to be an important step in the signal transduction pathway (Gloe et al., 1999). Incubation of neuroblastoma cells with $\mathrm{C}(\mathrm{YIGSR})_{3}-\mathrm{NH}_{2}$ peptide amide or antibody directed against the $67 \mathrm{kDa} \mathrm{LBP}$ induces tyrosine phosphorylation of proteins (Bushkin-Harav and Littauer, 1998). Further studies on the mechanism of signalling among the trophoblast cell surface, $32 / 67 \mathrm{kDa}$ $\mathrm{LBP}(\mathrm{s})$ and uterine decidual laminin are needed to increase understanding of the process of embryo implantation.

The authors thank H. Kleinman (National Institute of Dental Research, NIH, Bethesda, MD, USA) for kindly providing the $32 / 67$ $\mathrm{kDa}$ LBP IgG. This work was supported by the 'Climbing Project of China' program, the 100 Scientist-program in CAS, the Personal Department of China for Returned Scholars from abroad and State Key Laboratory of Reproductive Biology, Institute of Zoology, Chinese Academy of Sciences. 


\section{References}

Armant DR, Kaplan HA and Lennarz WJ (1986) Fibronectin and laminin promote in vitro attachment and outgrowth of mouse blastocysts Developmental Biology 116 519-523

Beck K, Hunter I and Engel J (1990) Structure and function of laminin: anatomy of a mutildomain glycoprotein FASEB Journal 4 148-160

Burrows TD, King A, and Loke YW (1996) Trophoblast migration during human placental implantation Human Reproduction Update 2307-321

Bushkin-Harav I and Littauer UZ (1998) Involvement of the YIGSR sequence of laminin in protein tyrosine phosphorylation FEBS Letters 424 243-247

Chambers BJ, Klein NW, Conrad SH, Ruppenthal GC, Sackett GP, Weeks BS and Kleinman HK (1995) Reproduction and sera embryotoxicity after immunization of monkeys with the laminin peptides YIGSR, RGD, and IKVAV Proceedings National Academy of Sciences USA 92 6818-6822

Clement B, Segul-Real B, Savagner P, Kleinman HK and Yamada Y (1990) Hepatocyte attachment to laminin is mediated through multiple receptors Journal of Cell Biology 110 185-192

Gloe T, Riedmayr S, Sohn H-Y and Pohl U (1999) The 67 kDa laminin-binding protein is involved in shear stress-dependent endothelial nitric-oxide synthase expression Journal of Biological Chemistry 274 15 996-16 002

Graf J, Ogle RC, Robey FA, Sasaki M, Martin GR, Yamada Y and Kleinman HK (1987) A pentapeptide from the laminin B1 chain mediates cell adhesion and binds the 67000 laminin receptor Biochemistry 226 6896-6900

Grant DS, Tashiro K, Segui-Real B, Yamada Y, Martin GR and Kleinman HK (1989) Two different laminin domains mediate the differentiation of human endothelial cells into capillary-like structures in vitro. Cell 58 933-943

Landowski TH, Dratz EA and Starkey JR (1995) Studies of the structure of the metastasis-associated $67 \mathrm{kDa}$ laminin-binding protein: fatty acid acylation and evidence supporting dimerization of the $32 \mathrm{kDa}$ gene produce to form the mature protein Biochemistry 3411 276-11 287

Mercurio AM and Shaw LM (1988) Macrophage interaction with laminin: PMA selectively induces the adherence and spreading of mouse macrophages on a laminin substratum Journal of Cell Biology 107 1873-1880
Mecham RP (1991) Receptors for laminin on mammalian cells FASEB Journal 5 2538-2546

Romagnano L and Babiarz B (1993) Mechanisms of murine trophoblast interaction with laminin Biology of Reproduction 49 374-380

Schlafke S and Enders AC (1975) Cellular basis of interaction between trophoblast and uterus at implantation Biology of Reproduction 12 41-65

Sutherland AE, Calarco PG and Damsky CH (1993) Developmental regulation of integrin expression at the time of implantation in the mouse embryo Development 119 1175-1186

Tashiro K, Sephel G C, Greatorex D, Sassaki M, Shirashi N, Martin GR, Kleinman HK and Yamada Y (1989) A synthetic peptide containing the IKVAV sequence from the A chain of laminin mediates cell attachment, migration and neurite outgrowth Journal of Biological Chemistry 26416 174-16 182

Thompson HL, Burbelo PD, Segul-Real B, Yamada Y and Metcalfe DD (1989) Laminin promotes mast cell attachment Journal of Immunology 143 2323-2327

Wewer UM, Damjanov A, Weiss J, Liotta IA and Damjanov I (1986) Mouse endometrial stromal cells produce basement-membrane components Differentiation 32 49-58

Yow H, Wong JM, Chen HS, Lee C, Steele GD and Chen LB (1988) Increased mRNA expression of laminin-binding protein in human colon carcinoma: complete sequence of a full-length cDNA encoding the protein Proceedings National Academy of Sciences USA 85 6394-6398

Zeng GQ and Cao YJ (1996) Co-culture of mouse embryos with uterine epithelial cells monolayer Acta Zoologica Sinica 42 212-217

Zhang CY, Cao YJ and Zeng GQ (1995) The model of murine ectoplacental cone implantation in vitro. Journal of Reproductive Medicine 4 173-174

Zhang CY, Cao,YJ and Zeng GQ (1996) Studies of murine ectoplacental cone cells interaction with laminin Acta Biologiae Experimentalis Sinica 29 125-131

Zhu ZM, Kojima N, Stroud MR, Hakomori S, and Fenderson BA (1995) Monoclonal antibody directed to $\mathrm{Le}^{\mathrm{Y}}$ oligosaccharide inhibits implantation in the mouse Biology of Reproduction 52 903-912 